\title{
Pregnancy in teenagers with heart disease
}

\section{Embarazo en pacientes adolescentes con cardiopatía}

\author{
Jorge E. Cossio-Aranda ${ }^{*}$, Jorge Gaspar-Hernández², Antonio Juanico-Enriquez ${ }^{3}$, \\ Fernando Rodríguez-Rosales ${ }^{1}$, Ana M. López-Jaramillo ${ }^{1}$, David A. Becerra-Vázquez', \\ Ernestina Pinal-Moreno ${ }^{1}$, María J. Díaz-Jiménez ${ }^{4}$, Norma Velázquez-Ramírez ${ }^{5}$, \\ Manuel Cortés-Bonilla ${ }^{6}$, Alejandro Ruiz-Toral', Daniel Pérez-Leos ${ }^{7}$, Alfonso Buendía-Hernández ${ }^{8}$, \\ Rafael Chávez-Domínguez ${ }^{9}$, Jorge A. Cardona-Pérez ${ }^{10}$, Marco Martínez-Ríos ${ }^{11}$, and \\ Guillermo Fernández-de la Reguera ${ }^{12}$
}

${ }^{1}$ Outpatient Department; ${ }^{2}$ Medical Directorate, and ${ }^{3}$ Pediatric Post-surgical Intensive Therapy Department, Instituto Nacional de Cardiología Ignacio Chávez; ${ }^{4}$ National Institutes of Health and High Specialty Hospitals Coordinating Commission; ${ }^{5}$ Department of Sexual and Reproductive Health and ${ }^{6}$ General Directorate Consultant's Office, Instituto Nacional de Perinatología; ${ }^{7}$ Department of Legal Affairs; ${ }^{8}$ Department of Pediatric Cardiology; ${ }^{9}$ Department of Epidemiology, Instituto Nacional de Cardiología Ignacio Chávez; ${ }^{10} \mathrm{General} \mathrm{Directorate,} \mathrm{Instituto} \mathrm{Nacional} \mathrm{de} \mathrm{Perinatología;}{ }^{11} \mathrm{General}$ Directorate and ${ }^{12}$ Medical Sub-Directorate, Instituto Nacional de Cardiología Ignacio Chávez, Mexico City, Mexico

\begin{abstract}
The prevalence of pregnancy in adolescent women is high in Mexico and represents a public health problem. The pregnant teenager with heart disease has a high probability of complications during pregnancy and the delivery, which carries a risk of death of both the mother and the product. In many cases the pregnancy should have been avoided, planned or interrupted, however the majority at this age is vulnerable and although certain cases must be interrupted by their high risk of maternal-fetal death, prevention and legal aspects should be considered. In some cases the woman wants a pregnancy although her health condition does not allow it, but there are options of adoption or recourse to a surrogate belly. In response to this growing social problem, the National Cardiology Institute Ignacio Chávez and National Institute of Perinatology, with the coordination of Ministry of Health in Mexico, started a pregnancy prevention module within a clinic of follow-up of cardiopathy and pregnancy. This review raises the global problem in our country that occupies the first place in pregnancies in adolescents, with more than 400,000 pregnancies a year and the form of immediate response in a multidisciplinary way.
\end{abstract}

Key words: Adolescent. Cardiopathy. Pregnant. High risk. Prevention. Mexico.

\section{Resumen}

La prevalencia de embarazo en mujeres adolescentes es muy alta en México, y representa un problema de salud pública. La adolescente embarazada con cardiopatía tiene altas posibilidades de complicaciones durante el embarazo y su resolución, lo que pone en riesgo la vida tanto de la madre como del producto. En muchos casos el embarazo debió ser evitado, planeado o interrumpido, sin embargo la mayoría a esta edad es vulnerable y si bien ciertos casos deben ser interrumpidos por su alto riesgo de muerte materno-fetal, es fundamental considerar la prevención y los aspectos legales. En algunos casos

\section{Correspondence:}

*Jorge Eduardo Cossio-Aranda

E-mail: doctorjorgecossio@yahoo.es
Available online: 09-02-2020

Arch Cardiol Mex (Eng). 2020;90(1):81-85 www.archivoscardiologia.com 2604-7063 / @ 2019 Instituto Nacional de Cardiología Ignacio Chávez. Published by Permanyer. This is an open access article under the CC BY-NC-ND license (http://creativecommons.org/licenses/by-nc-nd/4.0/). 
la mujer desea un embarazo aunque su condición de salud no se lo permite, pero existen opciones de adopción o recurrir a un vientre subrogado. Atendiendo este problema social cada vez más creciente, el Instituto Nacional de Cardiología Ignacio Chávez, en coordinación con la Comisión Coordinadora de la Secretaría de Salud y el Instituto Nacional de Perinatología, echaron a andar un módulo de prevención de embarazo dentro de una clínica de seguimiento de cardiopatía y embarazo. Esta revisión plantea el problema global en nuestro país, que ocupa el primer lugar en embarazos en adolescentes, con más de 400 mil embarazos al año y la forma de dar respuesta inmediata de manera multidisciplinaria.

Palabras clave: Adolescente. Cardiopatía. Embarazo. Alto riesgo. Prevención. México.

\section{Introduction}

Recently, the Organization for Economic Cooperation and Development reported that, among its 35 permanent members, Mexico is ranked first in adolescent pregnancy, with about half a million of pregnancies every year ${ }^{1}$. Of this group, $60 \%$ corresponds to low-income population that is unable to optimally have access to health services, education, healthy nutrition and better development opportunities for both the mother and the child. According to the 2015 Inter-census Survey of the National Institute of Statistics and Geography (INEGI - Instituto Nacional de Estadística y Geografía), in Mexico there are 48.7 million of females aged 12 years and older, out of which $67.3 \%$ have had at least one live birth. It is important pointing out that $7.8 \%$ of those aged between 12 and 19 years have already procreated, exercising their motherhood without having a couple in $27.8 \%$ of cases ${ }^{2}$.

Thus, adolescent girls have become one of the most vulnerable groups in our country and this represents a serious public health problem, since pregnant adolescents have twice higher probabilities of dying due to complications during pregnancy or delivery in comparison with adult women ${ }^{3}$, so much so, that it is the second cause of death between 15 and 19 years of age. In the INEGI inter-census survey in Mexico, the analysis of the global fertility rate by level of education shows that, the higher the level of education, the lower the fertility (Table 1), and in developing countries, adolescent girls usually have a low level of education and, in many cases, their pregnancy may be related to sexual abuse or violence, which adds high rates of sexually-transmitted diseases to the obstetric problem, including human immunodeficiency virus infection, whose burden is higher in females than in males ${ }^{4}$.

Currently, advances in diagnostic testing methods, surgical techniques, cardiopulmonary bypass circuits miniaturization and postoperative care have allowed to maintain a survival higher than $85 \%$ in patients with heart disease, especially with congenital conditions ${ }^{3}$. In the latter case, the surviving child population will reach reproductive age, whereby new health risks are created.
In the National Institute of Cardiology Ignacio Chávez, between 2003 and 2016, 4,000 pediatric patients were operated and, by 2016,640 of them had already become adults, out of which more than $50 \%$ were of the female gender, who represent a variable risk in case of combining pregnancy with a congenital heart disease ${ }^{5}$. For the cardiologist involved in the management of pregnant women with congenital or acquired heart disease, the primary goal should be the prevention of cardiovascular complications. Nevertheless, complication rates are extremely high, especially when there are heart diseases that significantly increase the risk of dying during gestation, such as primary pulmonary arterial hypertension and Eisenmenger syndrome, which have a mortality risk of between 30 and $50 \%$ during pregnancy ${ }^{6,7}$ (Table 2). Another example of high risk of morbidity and mortality in this group is the need for anticoagulation for arrhythmias and/or use of mechanical prostheses, which implies higher maternal and fetal risk. In addition to the risk that cardiovascular disease generates for the mother, cardiovascular drugs can pose a high risk to both the mother and the fetus during pregnancy ${ }^{8,9}$.

In the cases of mothers with congenital or acquired heart disease, fetal risk is $18 \%$, in comparison with that of the general population, which is $7 \%$, and it is reflected by delayed intrauterine growth, prematurity and intracranial hemorrhage, among other consequences ${ }^{10}$. Some heart defects have a dominant autosomal inheritance pattern, i.e., a mother with these types of defects can have a $50 \%$ probability for the child to be born with the same genetic defect.

\section{Emotional impact on women with heart disease and pregnancy}

Since the first years of this century, the topic "adolescent pregnancy" has occupied an important space in global public health because it affects physical and emotional health, and constitutes a social and economic problem, especially in a vulnerable group of countries with low economic income. 
Table 1. Overall fertility rate (total number of children that on average a woman will have at the end of her reproductive life) by level of education

\begin{tabular}{|l|c|c|c|}
\hline Level of education & $\mathbf{1 9 9 7 ^ { * }}$ & $\mathbf{2 0 0 0 ^ { * * }}$ & $\mathbf{2 0 1 4}^{\dagger}$ \\
\hline No instruction & 5.18 & 3.34 & 3.30 \\
\hline Incomplete primary education & 4.06 & 3.26 & 3.21 \\
\hline Complete primary education & 3.31 & 2.93 & 2.99 \\
\hline Secondary education & 2.75 & 2.70 & 2.70 \\
\hline Middle and higher education & 2.09 & 1.70 & 1.79 \\
\hline
\end{tabular}

Total fertility rate refers to the total number of children that on average woman will have at the end of her reproductive life.

*Corresponds to the 1992-1996 five-year period.

${ }^{*}$ Corresponds to the 2006-2008 triennium.

${ }^{\dagger}$ Corresponds to the 2011-2013 triennium.

Source: National Institute of Statistics and Geography, 2016².

Table 2. Conditions that put pregnant women with congenital heart disease at high risk

Conditions that put pregnant women with congenital heart
disease at high risk
- Eisenmenger syndrome
- Severe left ventricular outflow tract obstruction
- Severe right ventricular outflow tract obstruction
- Severe pulmonary artery hypertension
- Operated with Fontan surgical procedure
- Tricuspid atresia
- Corrected transposition
- Marfan syndrome

Source: Cossio-Aranda, $2002^{8}$.

There are investigations that show that a high percentage of adolescents lack education and information on sexuality and reproductive health. In Mexico, the Ministries of Health and Public Education have created policies with physical spaces and human resources to facilitate adolescent education, and to help them understand their sexuality and protect them against unwanted pregnancies, sexually-transmitted infections and the subsequent risk of sterility. However, these programs deserve more diffusion and actions of society in general.

The pregnant adolescent experiences mood alterations, with feelings of frustration, anger, irritability, hostility, guilt and shame. As pregnancy advances, she develops fear, concerns about dying, increased stress, symptoms of anxiety and depression, which impact on emotional health of the mother and the fetus. Therefore, psychological care aimed at the prevention of pregnancies in adolescents with heart disease is of the utmost importance, by making education on sexuality effective, focusing on the following aspects:

- Transmission of the concept of "comprehensive sexuality" with responsibility.

- Development of skills and attitudes that allow the training of autonomous people, able to make decisions to prevent and/or face the risks involved in the practice of sexuality.

- Generation of self-awareness on sexuality.

- Development or strengthening of social and assertive communication skills.

- Development of competences, abilities and attitudes that influence self-esteem.

- Motivation of adolescents to complete their education.

- Information of parents about adolescent girls' needs on sexuality issues and how to help them.

\section{Reproductive health and adolescent pregnancy prevention}

In view of the serious problem of maternal death, especially in adolescent females with heart diseases, the National Health Institutes and High Specialty Hospitals Coordinating Commission, within a multidisciplinary approach in collaboration with the National Institute of Perinatology and the National Institute of Cardiology Ignacio Chávez, has developed a program of high-risk pregnancy prevention.

For the accomplishment of this program, and with the support of medical and nursing authorities, a place for the care of patients of childbearing age and cardiovascular conditions, called high reproductive risk module (MARR - Módulo de Alto Riesgo Reproductivo), which 


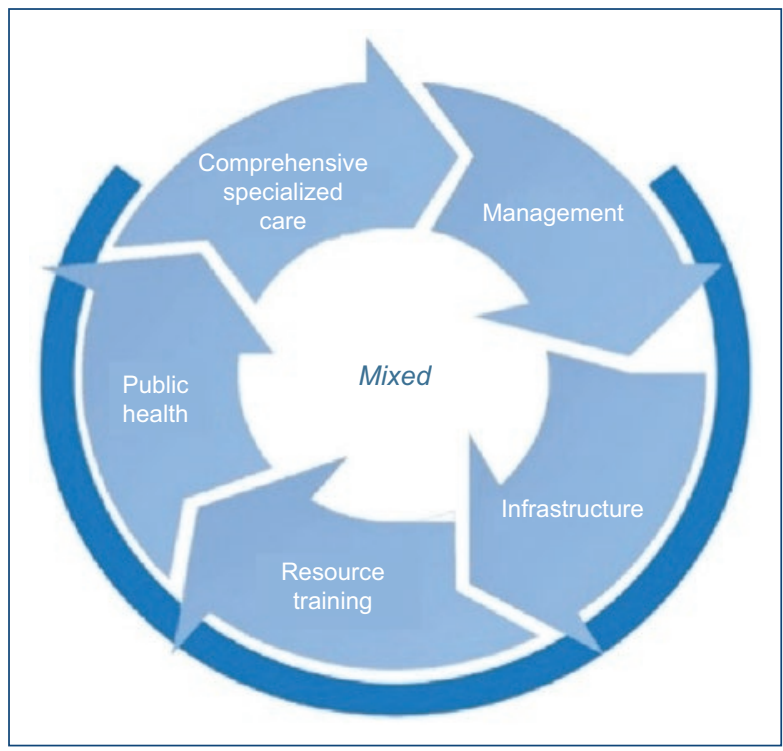

Figure 1. Classification aspects of the project of high reproductive risk modules.

involves the prevention of pregnancy in cardiac disease, especially in adolescents ${ }^{11}$, was implemented in the Outpatient Department of the National Institute of Cardiology Ignacio Chávez (Fig. 1).

The medical and nursing staff at MARR received training through theoretical and practical courses on pregnancy and contraceptive methods in heart disease patients, as well as the legal framework that should rule in this context.

This module has a prevention system based on truthful and timely information. It includes education and diffusion of pregnancy prevention mechanisms, genetic counseling and gynecological help for pregnancy prevention. In a legal framework, adolescent patients with heart disease are informed on the risk that pregnancy would entail for the mother and the fetus, and on the way to prevent it. To promote knowledge about reproductive risk and contraceptive methods, Ministry of Health official information material is distributed to patients with cardiac disease, and counseling and psychological support activities are also carried out in order to encourage the users to establish a reproductive life plan.

The use of the institutional electronic agenda allows keeping a record of patients cared for and thereby it is possible to generate a database that facilitates the report to be generated to the Ministry of Health on the advances, achievements and needs of the module, and it will also allow measuring the impact of the program on this group of patients.

\section{Legal framework, consequences and patient and doctor rights}

The Political Constitution of the Mexican United States establishes the human rights every person is entitled to with regard to being informed on pregnancy prevention in women with congenital heart disease and on the risk for her life and/or for the life of the fetus in gestation, which requires from us to safeguard these rights. Article 4 of said ordinance states that everyone has the right to freely, responsibly and duly informedly decide about the number and spacing of their children; in addition, it contemplates the protection of the right to health, and in the same train of thought, the Declaration of Human Rights, the Declaration of Rights and Duties of Man and the International Covenant on Civil and Political Rights converge in having contemplated the human right by excellence that is "life", which must be guarded and/or protected above other rights.

The alternatives for pregnancy prevention a woman with congenital heart disease has are adoption and surrogate motherhood. Adoption is the legal act whereby a person with legal capacity takes another's child as his own, with the purpose to establish a parental-filial relationship with him/her, thus contracting the same rights and obligations that are born from a consanguineous bond. The law provides that, in order to be able to adopt, the person who wants to do it must comply with a series of requirements, among which a minimum age of 25 years is cited. Surrogate motherhood involves using a medical practice known as assisted reproductive technology, whose purpose is to perform extracorporeal fertilization, i.e., outside the maternal body. This requires the intervention of the three following agents: the mother, the gestating woman and the treating physician, who in addition to informing those involved in the procedure, will apply said assisted reproduction technology under proper medical care and supervision in order to effectively bring that pregnancy to term. Article 3 of the Law for Surrogate Motherhood initiative defines surrogacy as "The medical practice consisting of human morulae implantation in a woman, which result from the binding of an ovule and a sperm fertilized by a couple bound by marriage or who cohabitate, and that contribute their genetic load or material that concludes with the delivery of a child". Thus, the legal relationship arises with the recognition of the woman of her child as her own, i.e., at the moment after the delivery, and by virtue of the above, once the purpose has been accomplished, the surrogate will hand the conceived child over to the biological mother, subrogating all acquired rights and 
obligations with regard to the newborn; to surrogate or to substitute is legally defined as the act of replacing a person in terms of rights and obligations; this is going to give rise to a legal bond called filiation. In short, there are two benefits that are obtained under this option: conceiving the fetus in a viable way exercising the right to reproductive health while preserving the ultimate legal good protected by the law: "life".

Considering that the woman would decide not to opt for adoption or surrogate motherhood and her posture is still to continue with the gestation period, the alternate way to protect "life" is legal termination of pregnancy, a procedure that the Federal District Statute of Health and its regulations stipulate as being free and that can be carried until before of the twelfth week of gestation.

Legal termination of pregnancy can be practiced after the twelfth week, without falling into the criminal figure of abortion (termination of pregnancy after the twelfth week of gestation) provided that the Federal District Criminal Code regulatory hypotheses, which indicate the situations where there is criminal liability exemption, are updated. These hypotheses establish situations such as when according to the judgement of the doctor who assists the procedure, with the support of the opinion of another doctor, both determine that not performing the abortion would put the life of the pregnant woman in serious danger, or when in the opinion of two medical specialists there is reason enough to diagnose that the fetus has genetic or congenital alterations that may result in severe physical or mental damage that can put its survival at risk.

\section{Conclusions}

In the face of a serious social and health problem in a vulnerable population group such as adolescent females, preconception counselling should be offered to all women with heart disease, maintaining a multidisciplinary care approach constantly emphasizing the importance of preventing pregnancy in adolescence and at all levels.

Despite the evident diversity between medical specialties, with the creation of a module of pregnancy prevention in adolescent and adult females at high risk of morbidity and mortality due to their heart disease, we hope to gather, integrate and complement the necessary elements for a multidisciplinary approach, as today's medicine demands, in order to achieve the ultimate desideratum: prevention, this time in defense of women's childbearing age.

\section{Acknowledgements}

We are especially grateful with Blanca Elena Rodríguez Hernández, Patricia López Colín and Ilián Alejandra Cruz Hernández for their active participation in this manuscript and in the creation of the pregnancy prevention module.

\section{Funding}

The present investigation has not received any specific aid from public or commercial sector agencies or nonprofit entities

\section{Conflict of interests}

The authors declare that they have no conflicts of interest.

\section{Ethical disclosures}

Protection of people and animal subjects. The authors declare that no experiments were performed on humans or animals for this study.

Confidentiality of data. The authors declare that no patient data appear in this article.

Right to privacy and informed consent. The authors declare that no patient data appear in this article.

\section{References}

1. Arceo-Gómez EO, Campos-Vázquez RM. (2014). Teenage pregnancy in Mexico: Evolution and consequences. Lat Am J Econ. 2014;51:109-46.

2. Instituto Nacional de Estadística y Geografía (INEGI). Encuesta Intercensal EIC 2015. México;2016.

3. Organización Mundial de la Salud. Mortalidad materna. https://www.who int/es/news-room/fact-sheets/detail/maternal-mortality

4. Secretaría de Salud Centro Nacional para la Prevención y el Control del VIH y el SIDA (Censida). Informe nacional de avances en la respuesta al VIH y el SIDA en México, 2015. Disponible en: http://www.censida. salud.gob.mx/descargas/ungass/GARPR_Mx2015.pdf

5. Departamento de Bioestadística del Instituto Nacional de Cardiología Ignacio Chávez

6. Khairy P Ouyang DW, Fernandes SM, Lee-Parritz A, Economy KE Landzberg MJ. Pregnancy outcomes in women with congenital heart disease. Circulation. 2006;113(4):517-24.

7. Elkayam U, Goland S, Pieper PG, Silversides CK High-risk cardiac disease in pregnancy. J Am Coll Cardiol. 2016;68:502-16.

8. Cossío-Aranda J. Cardiopatía congénita y embarazo. En: Fause A. Cardiopatía congénita en el adulto. Tercera edición. Elsevier Science;2002.

9. Salazar E, Izaguirre R. Heart disease, anticoagulants and pregnancy. Rev Esp Cardiol. 2001;54(Suppl 1):8-16.

10. Salazar E, Izaguirre R, Verdejo J, Mutchinick O. Failure of adjusted doses of subcutaneous heparin to prevent thromboembolic phenomena in pregnant patients with mechanical cardiac valve prosthesis. J Am Coll Cardiol. 1996;27:1698-703.

11. Cardona A, Cortés M, Velázquez N, Díaz MJ, Varela Y, Figueroa R. Proyecto de atención preventiva de mujeres con alto riesgo reproductivo. Perinatol Reprod Hum. 2017;31:96-104. 